\title{
Participatory evaluation of groundnut planting methods for pre-harvest aflatoxin management in Eastern Province of Zambia
}

\author{
Mweshi Mukanga ${ }^{1, *}$, Limbikani Matumba ${ }^{2}$, Beatrice Makwenda ${ }^{3}$, Sharon Alfred ${ }^{4}$, Whytson Sakala ${ }^{5}$, \\ Kennedy Kanenga ${ }^{6}$, Tim Chancellor ${ }^{7}$, Jonas Mugabe ${ }^{8}$ and Ben Bennett ${ }^{7}$ \\ ${ }^{1}$ Mount Makulu Central Research Station, Zambia Agriculture Research Institute, Private Bag 7, Chilanga, Zambia \\ ${ }^{2}$ University of Lilongwe for Agriculture and Natural Resources, NRC Campus, P.O. Box 143, Lilongwe, Malawi \\ ${ }^{3}$ National Small-Scale Farmer Association of Malawi (NASFAM), City Centre, P.O. Box 30716, Lilongwe 3, Malawi \\ ${ }^{4}$ Food Agriculture Natural Resources Policy Analysis Network (FANRPAN), 141 Cresswell Street, Weavind Park, 0184 Pretoria, South Africa \\ ${ }^{5}$ Farmers Out grower Foundation Limited, Off Airport Road, Katopola Area, Chipata, Zambia \\ ${ }^{6}$ Msekera regional Research Station, Zambia Agriculture Research Institute, P.O. Box 510089, Chipata, Zambia \\ ${ }^{7}$ Natural Resources Institute, Greenwich University, Old Royal Naval College, Park Row, London SE10 9LS, UK \\ ${ }^{8}$ Forum for Agricultural Research in Africa (FARA), 12 Anmeda Street, Roman Ridge PMB CT 173, Accra, Ghana
}

\begin{abstract}
Aflatoxin contamination remains a major challenge for smallholder groundnut producers in Southern Africa. This is compounded by the stringent aflatoxin regulatory regimes in the lucrative international markets that continue to deny groundnuts produced in this region the access to markets. Participatory on-farm experiments were carried in 2016 and 2017 in Chinkhombe (Katete) and Kalichero (Chipata), and on-station trials at Mount Makulu Central Research Station (Chilanga) to evaluate the efficacy of groundnut planting methods: planting in double rows, single rows, tied ridges and on flatbeds, for pre-harvest aflatoxin management. Planting on flatbeds (no ridges), a popular planting method in most parts of Zambia was designated as the baseline. Significantly low $(p<0.05)$ levels of aflatoxin, $(10.3 \pm 3.1 \mu \mathrm{g} / \mathrm{kg})$ were recorded in the groundnuts planted on tied ridges, and less than $22 \%$ of these had aflatoxin levels above the Zambia regulatory limit of $10 \mu \mathrm{g} / \mathrm{kg}$, compared to more than $40 \%$ in other methods. Except for double rows, significantly higher pod yield, $1193 \mathrm{~kg} / \mathrm{ha}$, was recorded in groundnuts planted on tied ridges compared to other pre-harvest management options. A reduction of 37 and $81 \%$ in aflatoxin contamination was observed in groundnuts planted on single rows and tied ridges, respectively compared to an increase of $39.2 \%$ in double rows above $54.3 \pm 10.9 \mu \mathrm{g} / \mathrm{kg}$ recorded in flatbeds. In addition, tied ridging was observed to improve plant vigour, lower disease incidence, insect pest and weed infestation. It is clear that the evaluation of these practices on-farm enabled more farmers to be more aware of the effects of these methods and get motivated to adopt them. It is thus imperative that participatory on-farm evaluations of existing aflatoxin management options are carried out as they are an essential step in influencing adoption and uptake of preharvest management control methods among smallholder farmers.
\end{abstract}

Keywords: aflatoxin / groundnuts / pod yield / participatory approach / pre-harvest

Résumé - Évaluation participative des pratiques culturales pour limiter les aflatoxines avant récolte dans la Province de l'Est de la Zambie. La contamination par les aflatoxines est un défi majeur pour les petits producteurs d'arachide d'Afrique australe. À cela s'ajoutent les régimes réglementaires très stricts en matière d'aflatoxines appliqués sur les lucratifs marchés internationaux, qui continuent de refuser l'accès à ces marchés aux arachides produites dans cette région. Des expériences participatives ont été menées en 2016 et 2017 avec les paysans de Chinkhombe (Katete) et Kalichero (Chipata), et des essais en station à la station de recherche centrale du Mont Makulu (Chilanga) pour évaluer l'efficacité de plusieurs méthodes de plantation d'arachide : plantation en rangées doubles, en rangées simples, en billons cloisonnés et à plat, afin d'essayer de limiter les aflatoxines avant la récolte. La plantation à plat (sans billons), une méthode de plantation populaire dans la plupart des régions de la Zambie, a été choisie comme référence. Des niveaux significativement faibles $(p<0,05)$ d'aflatoxines $(10,3 \pm 3,1 \mu \mathrm{g} / \mathrm{kg})$ ont été enregistrés dans les arachides

${ }^{*}$ Corresponding author: mmweshi@gmail.com 
plantées sur des billons cloisonnés, et moins de $22 \%$ d'entre elles présentaient des niveaux d'aflatoxines supérieurs aux limites réglementaires de $10 \mu \mathrm{g} / \mathrm{kg}$ en Zambie, comparé à plus de $40 \%$ avec les autres méthodes. À l'exception des rangées doubles, des rendements en gousses significativement plus élevés $(1193 \mathrm{~kg} / \mathrm{ha})$ ont été enregistrés sur les billons cloisonnés, par rapport aux autres méthodes. Une réduction de 37 et $81 \%$ de la contamination par les aflatoxines a été observée dans les arachides plantées en rangées simples et sur des billons cloisonnés, respectivement, comparativement à une augmentation de 39,2\% pour les rangées doubles, au-dessus des $54,3 \pm 10,9 \mu \mathrm{g} / \mathrm{kg}$ observés dans la culture à plat. En outre, il a été observé que les billons cloisonnés amélioraient la vigueur des plantes, réduisaient les maladies, les insectes et les mauvaises herbes. Il est clair que l'évaluation de ces pratiques dans leurs propres champs a permis à davantage d'agriculteurs d'être plus conscients des effets de ces méthodes et de se motiver pour les adopter. Il est donc nécessaire que des évaluations participatives des diverses pratiques de limitation des aflatoxines soient effectuées, car elles constituent une étape essentielle dans l'adoption de ces pratiques culturales en Zambie.

Mots-clés : aflatoxine / arachide / rendement en gousses / approche participative / pré-récolte

\section{Introduction}

Groundnut (Arachis hypogaea L.) is one of the dominant food and cash crops in Zambia that enables most smallholder farmers to earn a livelihood (Mofya-Mukuka and Shipekesa, 2013). The main groundnut producing areas are: Eastern (31\%), Central (17.2\%), Southern (13.7\%) and Northern provinces (9.2\%) (CSO, 2016). Eastern province is highly suited for groundnuts cultivation due to its high rainfall, on average $980 \mathrm{~mm}$ per year, as well as it's coarse textured and sandy loam soils. There are 308119 groundnut households in the province, of which $53.2 \%$ are actively involved in groundnut production. In 2013-14 season, they produced 54000 MT (CSO, 2016). As such, Chapoto and Chisanga (2016) suggested that, improving the performance of the groundnut sector holds a significant opportunity for improving smallholder livelihoods in this province and this is magnified by the global producer prices for groundnuts that have continued to rise mainly as a result of the growing demand in Asia especially China for groundnut oil (Business Standard, 2018). Worldwide, there is a high demand for organic aflatoxin-free organic produced groundnuts compared to conventionally grown groundnuts (Guerena and Adam, 2008). Tapping into this export opportunity holds significant promise for diversifying Zambia's agricultural sector and decreasing rural poverty.

However, despite the importance of the crop among smallholder farmers in the country, groundnut production has continued to decline due to the presence of pests and diseases including aflatoxin (Ross and Klerk, 2012). Aflatoxins are a group of structurally related toxic polyketide-derived secondary metabolites produced by certain strains of Aspergillus flavus and A. parasiticus and pose serious human and livestock health concerns (CAST, 2003). Pre-and post-harvest infection by Aspergillus spp. and the environmental factors that lead to aflatoxin accumulation in groundnuts have been reviewed in detail (Bandyopadhyay et al., 2016; Villers, 2014; Waliyar et al., 2015). The pre-harvest aflatoxin contamination of groundnut is favoured by soil type, drought stress, heat, and high soil temperature. The occurrence of these favourable conditions causes aflatoxin contamination to occur in the kernels and on the pods in the soil a few days or weeks before harvest (Cotty and Mellon, 2006). In addition, smallholder farmers in sub-Saharan Africa grow groundnuts under low input conditions (Monyo et al., 2009; Waliyar et al., 2015). It's possible with the absence of inorganic fertilizers, pesticides and other synthetic chemicals including fungicides in these traditional crop production systems, high levels of aflatoxins are likely to occur (Winter and Davis, 2006). The occurrence of high levels of aflatoxin repudiate any benefits associated with access to the lucrative American, European, and Middle-East markets (Matumba et al., 2015; Ross and Klerk, 2012).

While the management of aflatoxin contamination in groundnuts may be complex, some cultural practices such as: pre-season ploughing, early planting to escape periods of midseason and end season drought, use of biocontrol agents, maintaining good plant density in the fields, removal of premature dead plants, managing both field and storage insect pests and diseases, timely harvesting, exclusion of damaged and immature pods, and storing the pod/seed with less than $10 \%$ moisture content have been identified to be effective in preventing fungal infection and proliferation (Bandyopadhyay et al., 2016; Guchi, 2015). Several such pre-and post harvest aflatoxin mitigation practices have been promoted as good agricultural practices (Munsaka, 2013; Waliyar et al., 2008; 2015). However, most of the pre-harvest management options though cost-effective and practical under subsistence or smallscale farming conditions, have remained largely un-adopted by farmers and the levels of aflatoxin along the groundnut value chain have continued to be high (Njoroge et al., 2016). Several factors have been cited to explain the lack of adoption. Among them: lack of knowledge and information regarding aflatoxin control, negative perceptions about the effectiveness of the control measures, and lack of resources to implement the control methods (Marechera and Ndwiga, 2014; Monyo et al., 2009). A number of studies have shown that if the farmers are increasingly exposed to these technologies through on-farm trials and beneficial aspects are well understood, farmers would be motivated to adopt them (Freeman et al., 2002; Simtowe et al., 2016; Sugri et al., 2017). However, most onfarm demonstration and assessment trials have focused on combining mitigation factors such as host/cultivar resistance, soil amendments, use of biological control agents, timely harvest and postharvest drying, use of good quality seed and adjustment in plant date to avoid mid- and late-season drought (Bandyopadhyay et al., 2016; Waliyar et al., 2008), neglecting simple agricultural practices such as proper field/soil preparations, timely planting, mulching and ridging, etc. 


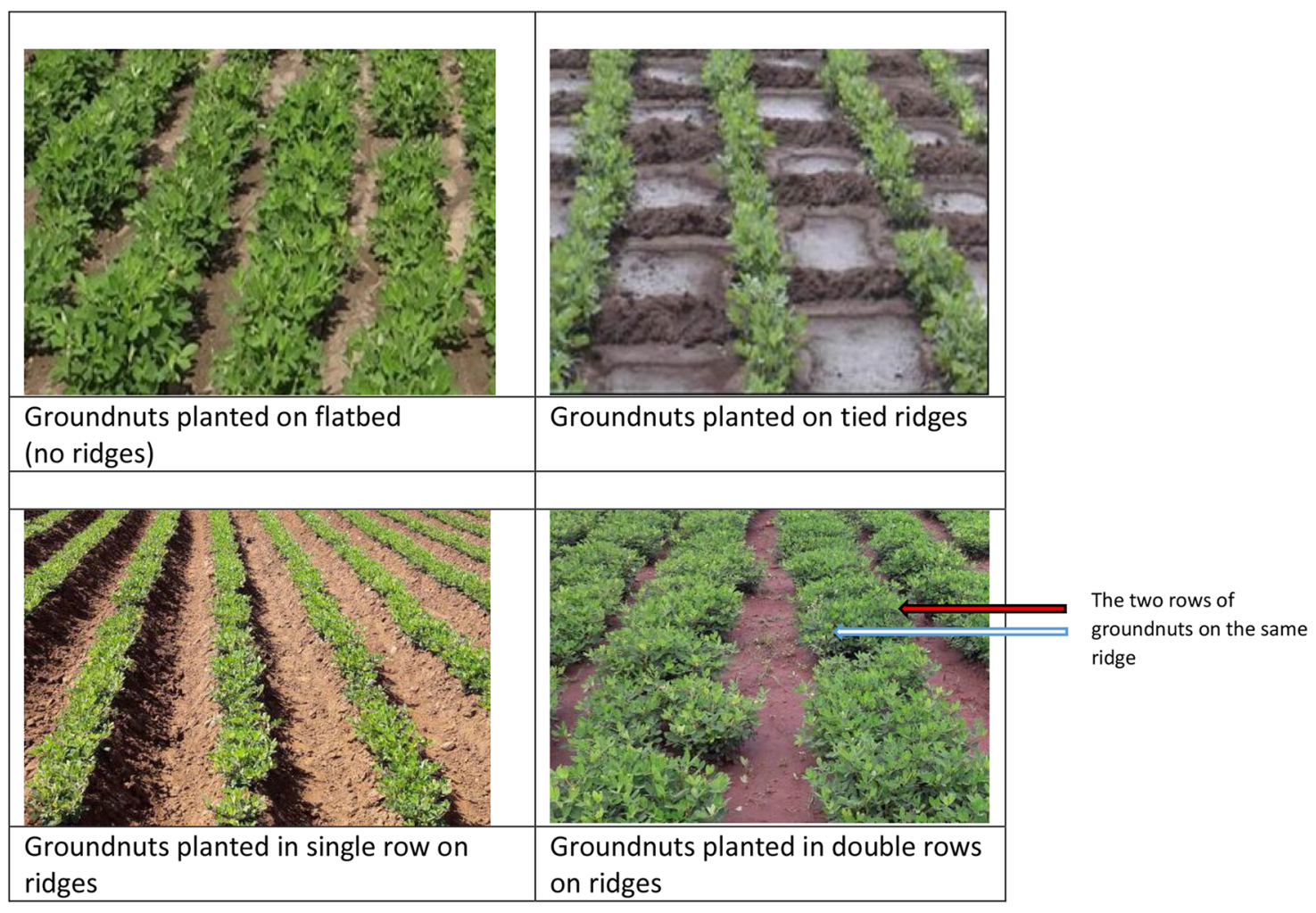

Fig. 1. The four planting methods: flatbed, tied ridges, single row and double rows.

Fig. 1. Les quatre méthodes de plantation: à plat, billons cloisonnés, rangées simples et rangées doubles.

These form part of the groundnut production guidelines (or package) and are relatively easy to apply within the farmer's setting, however, they have rarely been assessed for minimizing aflatoxin contamination. These practices usually require minor farm management adjustments when being implemented within a particular farming system, and have a lower risk premium; hence, have a higher chance of being adopted by smallholder farmers (Muzari et al., 2012). Therefore this study evaluated, validated and demonstrated on-farm the efficacy of four planting methods previously popularized by research and extension in Eastern Zambia.

\section{Materials and methods}

\subsection{On-farm and researcher managed trials}

Four field planting methods: double row, single row, tied ridge and flatbed (no ridges) were evaluated in on-farm experiments in two agricultural camps: Chinkhombe, Katete district $\left(\mathrm{S} 14^{\circ} 1^{\prime} 60, \mathrm{E} 31^{\circ} 55^{\prime} 60 ; 1069\right.$ metres above sea level (masl)) and Kalichero, Chipata (S13 2660', E 32 $21^{\circ}$ '1; $1040 \mathrm{~m}$ asl) in Eastern Zambia and in the researcher managed trials at Mount Makulu Central Research Station, Chilanga (S 15 32'52'; E 28 ${ }^{\circ} 14^{\prime}$ 54'; $1206 \mathrm{~m}$ asl) (Figures 1 and 2 ). The two agricultural camps were purposively selected because of their high groundnut production, slight over $15 \%$ of the total area under cultivation in the respective districts, and were also serviced by the Farmer out Grower Foundation Limited (FoF Ltd), a private sector agricultural trading company, one of the project partners. According to the Department of Agriculture

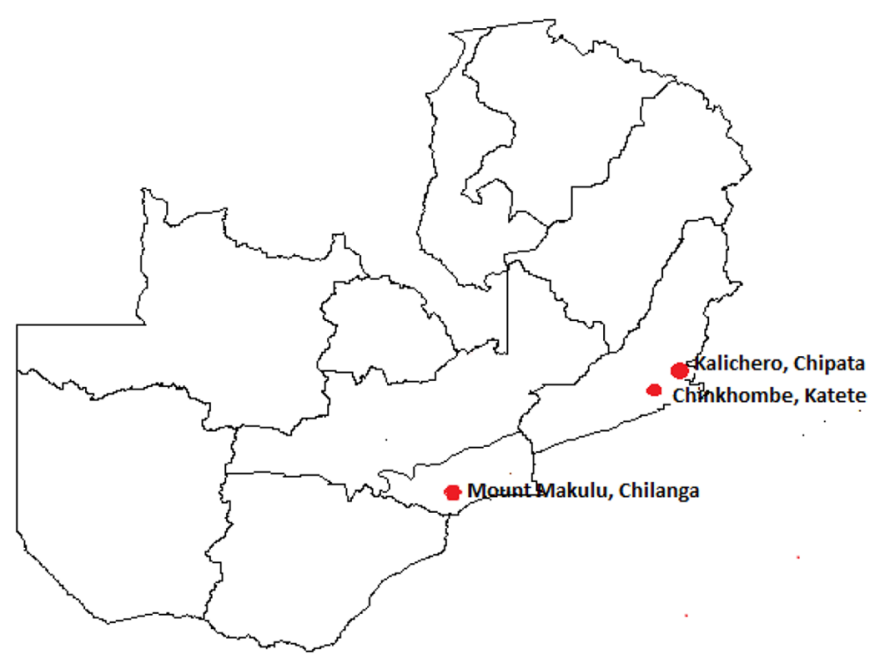

Fig. 2. Map of Zambia showing the location of the three sites (Source: https://en.wikipedia.org/wiki/Outline_of_Zambia\#/media/ File:Zambia_districts.png).

Fig. 2. Carte de la Zambie et localisation des trois sites d'étude.

Farmer Register of 2016, there were 1148 and 2113 groundnut growing households in Chinkhombe and Kalichero, respectively. All the three sites are located in agro-ecological region II, which is characterized by a rainy season from November to April with a total annual rainfall of between $800-1000 \mathrm{~mm}$ (Bunyolo et al., 1995). The rainfall is generally well 
distributed. The length of the crop growing period ranges from 100 to 140 days. Mean daily temperature during the growing season range from 23 to $25^{\circ} \mathrm{C}$. The soils in Chinkhombe are typical Alisols, moderately weathered and strongly leached with high cation exchange capacity (CEC) greater than $24 \mathrm{meq} / 100 \mathrm{~g}$ clay with variable texture, mainly loamy coarse sand, while those in Kalichero are Luvisols, slightly weathered and moderately leached and with a CEC $>24$ meq and high base saturation $>50 \%$ (JAICAF, 2008). The soil at Mount Makulu are mainly Acrisols, loamy sand or sandy loam, CEC less than $24 \mathrm{meq} / 100 \mathrm{~g}$ clay and base saturation $<50 \%$, strong to moderate acidic (Soil pH 4.7-5.3). Since groundnuts are normally planted in late December in these sites, 2015-2016 and 2016-2017 cropping seasons were designated as 2016 and 2017, respectively.

Before commencement of on-farm trials, pre-season group meetings were arranged in November, 2015 with village headmen and extension staff to discuss the aims and objectives of the study and to allocate planting method treatments to the participating farmers. Strategies for seed distribution, data and groundnut sample collection for aflatoxin analysis at harvest were discussed. In each of the two agricultural camps, the farmers were organized into a group, each with a group leader who acted as the contact point between the farmers and the research team. The team comprised an agronomist, a plant breeder, a mycotoxin specialist, a statistician, and a technology dissemination specialist.

However, at the trial commencement meetings in Chinkhombe and Kalichero in December, 2015 in both Kalichero and Chinkhombe, most of farmers indicated that they had already planted groundnuts using one of the proposed treatments to be evaluated in the study. As such for the purpose of comparing the treatments, the research team designated flatbed as the control as it is a widely used practice in many parts of Zambia (ZARI, 2008). In order to get quantitative analyzable data, farmers were asked by the investigators to set aside $10 \times 10 \mathrm{~m}$ plots of their farmland for the trial. Furthermore, only the farmers that had planted MGV-4 were eligible for the study. MGV-4 is a Virginia bunch variety that matures in 120-140 days, is easy to harvest and produces red uniform, medium-sized kernels with a good shelf life i.e., an oleic/linoleic $(\mathrm{O} / \mathrm{L})$ ratio of 1.5 . Based on this criteria, in 2016 eighty (80) farmers were selected to participate in the on-farm trials. Though the four planting methods were not equally distributed among the participating farmers, they were well replicated within each agricultural camp, and also served as demonstration plots or focal points for discussion during field days.

In 2017, only fourteen (14) lead farmers from each of the two agricultural camps participated in the trials, giving a total of 28 participants. According to the farmer register and village headmen, each of these lead farmers had 10 to 15 follower farmers. A few number of farmers participated in 2017 on-farm trials so that the fields set aside for the treatments were of the same size, timely planting, weeding and harvesting carried out and pod yield determined. Henceforth, each participating farmer agreed to make available 0.02 ha (or $20 \times 10 \mathrm{~m}$ ) of their farmland for the trials, which was then sub-divided into two equal plots, $100 \mathrm{~m}^{2}$ each. Each sub-plot was prepared and planted to using one of the two planting methods allocated to each farmer. The crop, groundnut variety MGV-4, was planted during the first week of December in both camps.

The majority of smallholder farmers do not apply any inorganic fertilizers or pesticides including fungicides, mainly due to lack of financial resources (Ross and Klerk, 2012). Unlike hybrid maize, cotton or tobacco which have a stable market and given priority in terms of inputs, groundnut is perceived to be female-controlled, therefore requiring minimal production costs, mainly labour. However, some farmers with animals and those with agroforestry trees in their fields rely on animal manure from dropping of the animals after harvest, and agroforestry leaves/litter to sustain soil fertility. Henceforth, no inorganic fertilizers or pesticides were applied in the on-farm trials.

During field days, farmers' opinions and perceptions were solicited using a semi-structured questionnaire about the performance of the crop and the different planting methods. At harvest, in both 2016 and 2017 seasons, $5 \mathrm{~kg}$ of unshelled groundnuts were collected from a thoroughly mixed sample of harvested groundnuts from each treatment (plot) for aflatoxin analysis.

The researcher-managed trials at Mount Makulu were planted in a randomized complete block design with four replications with each plot size measuring $4 \times 5 \mathrm{~m}^{2}$. The test crop was same as in the on-farm trials i.e. MGV-4. It was planted at a spacing of $0.75 \times 0.10 \mathrm{~m}$. All standard crop management practices including a basal fertilizer dose of $30 \mathrm{~kg} \mathrm{~N} / \mathrm{ha}$ and $60 \mathrm{~kg} \mathrm{P}_{2} \mathrm{O}_{5} /$ ha was applied at the time of soil preparation and 2-3 weedings (at 20 and 30-35 days) after sowing. During 2017 season, the crop had to be replanted during the third week of January after the initial crop planted in December 2016 failed to germinate. At harvest, pod yield from each plot was determined, thereafter $5 \mathrm{~kg}$ of unshelled groundnuts were collected for aflatoxin analysis, in the same way as in the on-farm trials.

\subsection{Aflatoxin analysis}

A hundred and eight (108) groundnut samples from onfarm trials i.e. 80 and 28 samples in 2016 and 2017, respectively; and 32 samples from researcher-managed trials, i.e. 16 from each of the two seasons were submitted for aflatoxin analysis. In each case, the harvested pods were shelled (approximatively, $5 \mathrm{~kg}$ pod/plot yield gave $3.5 \mathrm{~kg}$ shelled kernels), pooled, mixed thoroughly and a kilogram of this sample was removed by trained laboratory personnel and milled. Aflatoxin was then extracted from a $25 \mathrm{~g}$ test portion drawn from the milled aggregate in order to reduce sampling error (Giesbrecht and Whitaker, 1998; Whitaker et al., 1974, 1995).

The quantitation of total aflatoxins (B1, B2, G1, and G2) concentration was performed following Reveal ${ }^{\mathbb{B}} \mathrm{Q}+$ aflatoxin test $\left(\right.$ Neogen ${ }^{\mathbb{B}}$ ) supply instruction (Neogen Food Safety, Lansing, MI). Reveal ${ }^{\mathbb{B}} \mathrm{Q}+$ for AFs is a single-step lateral flow immunochromatographic assay based on a competitive immunoassay format for the quantitative testing. Aflatoxin concentration was measured in micrograms per kilogram ( $\mu$ g per kg). 
Table 1. Analysis of variance of total aflatoxins across two cropping seasons, 2016 and 2017, and pod yield in 2017 season.

Tableau 1. Analyse de variance des aflatoxines totales pendant deux saisons de culture, 2016 et 2017, et du rendement en gousses en 2017.

\begin{tabular}{lll}
\hline Source of variance & d.f. & Mean square \\
\hline
\end{tabular}

(a) Level of aflatoxins (log10 transformed)

\begin{tabular}{llr} 
Season & 1 & $1.812^{\mathrm{a}}$ \\
Location & 2 & $10.692^{\mathrm{b}}$ \\
Planting method & 3 & $2.230^{\mathrm{b}}$ \\
Year $\times$ Location & 2 & $5.011^{\mathrm{b}}$ \\
Year $\times$ Planting method & 3 & 0.461 \\
Location $\times$ Planting method & 6 & 0.084 \\
Year $\times$ Location $\times$ Planting method & 6 & 0.172 \\
& & \\
(a) Pod yield $(\mathrm{kg} / \mathrm{ha})$ & & \\
Location & 2 & $103864.39^{\mathrm{b}}$ \\
Planting method & 3 & $322899.43^{\mathrm{b}}$ \\
Location $\times$ Planting method & 6 & 32258.61 \\
\hline
\end{tabular}

\footnotetext{
${ }^{\mathrm{a}}$ indicates significance at $p=0.01$.

${ }^{\mathrm{b}}$ indicates significance at $p=0.05$.

$\mathrm{a}, \mathrm{b}$ : significatif à $p=0,01$ et $p=0,05$, respectivement.
}

\subsection{Data analysis}

Aflatoxin data were $\log$ transformed $(\mathrm{Y}=\ln [\mathrm{Y}+0.5])$ to stabilize error variance and subjected to analysis of variance by the general linear model procedure using Genstat 18th Edition (VSN International, 2015). Means of the transformed data were back transformed and compared using Tukey's honestly significant difference (HSD) test at 5\%. However, actual means are presented for clarity. Pod yield data converted to yield per hectare and analyzed using analysis of variance and compared using the Tukey's HSD test. All data were analyzed using Genstat 18th Edition (VSN International, 2015).

\section{Results}

\subsection{Aflatoxin analysis}

Significant $(p<0.05)$ season, location, planting methods and season by planting method effects were observed for the levels of aflatoxins in groundnuts (Tab. 1). Among the treatments, significant differences were observed only between double row and single row, double row and tied ridging, and flatbed and tied ridging (Tab. 2). Although due to natural variability of aflatoxins, some groundnut samples showed very high values (e.g. 249.5, 278 and $784.8 \mu \mathrm{g} / \mathrm{kg}$ ) and the ranges of aflatoxin content overlapped in both years (2016 and 2017). However, geometric means for the four treatments were comparatively lower in 2016 than in 2017 (Tab. 3).

The results of the ANOVA show that over the two seasons, the highest level of aflatoxins was recorded in double rows $(75.6 \pm 23.9 \mu \mathrm{g} / \mathrm{kg})$, followed by flatbeds $(54.3 \pm 10.9 \mu \mathrm{g} / \mathrm{kg})$. The lowest was in tied ridges $(10.3 \pm 3.1 \mu \mathrm{g} / \mathrm{kg})$. Amount of contamination in double rows was consistently higher over the two seasons and on average 7.3 times more than in tied ridges
(Tab. 3). In comparisons to flatbeds, groundnuts planted in single rows and tied ridges showed $32-40.5$ and $70-87.2 \%$ less aflatoxins, respectively. On the other hand, there was between $12-95 \%$ more aflatoxins in groundnuts in double rows (Tab. 3). The results presented in the same table also indicate that in 2016 , more than $58 \%$ of the groundnuts in double row, single row, and flatbed, compared to $21 \%$ in tied ridges, had aflatoxin contamination levels that exceeded the limit used in Zambia and in the Common Market for Eastern and Southern Africa [COMESA] $(10 \mu \mathrm{g} / \mathrm{kg})$, in the European Union [EU] $(4 \mu \mathrm{g} /$ $\mathrm{kg})$, and in the USA $(20 \mu \mathrm{g} / \mathrm{kg})$. However, in 2017 , only groundnuts planted in double rows and on flatbeds had more groundnuts with aflatoxin exceeding the three regulatory limits. On average less than $22 \%$ of the groundnuts in the tied ridges in 2016 and 2017, respectively exceeded the $10 \mu \mathrm{g} / \mathrm{kg}$ limit, which is Zambia and COMESA regulatory limit (Tab. 3).

Across the three sites, Chinkhombe, Kalichero, and Mount Makulu, the levels of aflatoxin contamination recorded in 2016 were within the same range except for the tied ridges (Tab. 4). The highest contamination was recorded in the researchermanaged fields at Mount Makulu in 2017, which was on average 50 to 100 times more than levels observed on-farm for the same season. On the contrary, the highest levels of contamination in the on-farm trials occurred in 2016 as opposed to 2017.

\subsection{Pod yield $(\mathrm{kg} / \mathrm{ha})$}

The pod yield per hectare for the different treatments at Chinkhombe, Kalichero, and Mount Makulu are presented in Figure 3. The mean pod yields were significantly higher $(p<0.05)$ in the double rows than in the other treatments except with single rows and tied ridges at Chinkhombe. Across the three sites, the lowest pod yields were obtained in the flatbeds $(1023,928$ and $893 \mathrm{~kg} / \mathrm{ha})$. The overall order of ranking in pod yield was: double row $>$ tied ridge $>$ single row $>$ flatbed.

\subsection{Farmer's perceptions}

The summary of the key observations by smallholder farmers on the four planting methods is presented in Table 5 . Although the farmer interviews were only conducted in 2017 during field days and at harvest, more than $90 \%$ of the interviewed farmers indicated that planting groundnuts in double rows on ridges produced smaller pods even though the yields were slightly higher than in other treatments. When asked about the growth of the crop and its appearance before maturity, they indicated that the crop planted on tied ridges exhibited improved plant vigour, less weedy, had a low disease and insect pest infestation and more drought tolerant than other planting methods. Although the groundnut crop planted in single rows performed better than those planted in double rows and on flatbeds, the crop in double rows had more roots with a carbon black or brown appearance (aflaroot) compared to the rest. Farmers indicated planting in either double rows or on tied ridges increased yields. However, in terms of labour requirements, farmers overwhelmingly indicated that preparing tied ridges was more labour demanding, followed by planting in double-rows. Overall, they found the four planting methods 
Table 2. Total aflatoxins (AFB1 + AFB2 + AFG1 + AFG2) mean differences between the different planting methods for using Tukey's HSD test. Tableau 2. Différences moyennes en aflatoxines totales $(A F B 1+A F B 2+A F G 1+A F G 2)$ entre les différentes méthodes de plantation selon le test HSD de Tukey.

\begin{tabular}{lllll}
\hline Treatment (A) & Treatment (B) & Mean diff (A-B) & Std.Error & Significance \\
\hline Double row & Flatbed & 21.3 & 16.16 & 0.19 \\
& Single row & $41.82^{\mathrm{a}}$ & 16.06 & 0.01 \\
Flatbed & Tied ridging & $65.25^{\mathrm{a}}$ & 15.97 & 0.00 \\
\multirow{2}{*}{ Single Row } & Single row & 20.5 & 15.85 & 0.20 \\
& Tied ridging & $43.94^{\mathrm{a}}$ & 15.75 & 0.01 \\
\hline
\end{tabular}

a The Mean difference is significant at 0.05 level.

${ }^{a}$ La différence moyenne est significative à $p=0,05$.

Table 3. Total aflatoxin (AFB1 + AFB2 + AFG1 + AFG2) range, mean, and number (percentage) of samples with a total aflatoxin level greater than various regulatory limits, from the experimental fields in 2016 and 2017.

Tableau 3. Aflatoxines totales (AFB1+AFB2 + AFG1 +AFG2): taux, moyenne et nombre (pourcentage) d'échantillons avec un taux d'aflatoxines total supérieur aux diverses limites réglementaires, issus des parcelles expérimentales en 2016 et 2017.

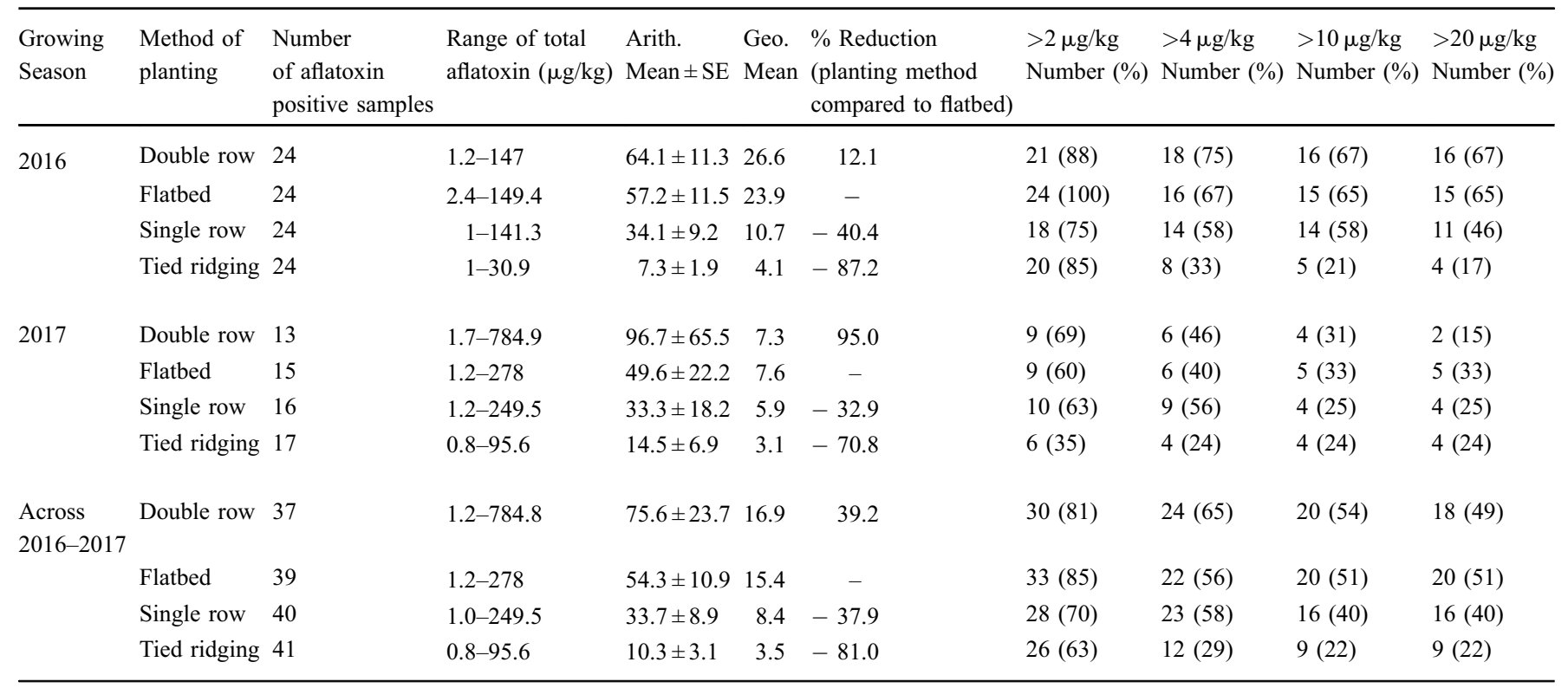

Total aflatoxin limit for human consumption by Joint FAO/WHO is $2 \mu \mathrm{g} / \mathrm{kg}$, while for EU, COMESA and USA, the total aflatoxin limit is 4,10 and $20 \mu \mathrm{g} / \mathrm{kg}$. SE = standard error of mean; Arith = arithmetic; Geo= Geometric.

La limite d'aflatoxines totales pour la consommation humaine est de $2 \mu \mathrm{g} / \mathrm{kg}$ pour la FAO et l'OMS, alors que pour l'UE, le COMESA et les USA, la limite est de 4,10 et $20 \mu \mathrm{g} / \mathrm{kg}$. SE=erreur type de la moyenne; Arith=arithmétique; Geo=geométrique.

were easy to carry out though making tied ridges required a slight more extra labour. The ranking of the planting methods were of the order: tied ridges $>$ double row $>$ single row $>$ flatbeds.

\section{Discussion}

Planting groundnuts on tied ridges reduced aflatoxin contamination in groundnuts by as much as $80 \%$ compared to the other three methods i.e. planting in double rows, single rows and on flatbeds (no ridging). The high soil moisture retention in the inter-row "ponds" in tie-ridging has been associated with reduced aflatoxin build-up in the maturing pods (Gebreselassie et al., 2014). According to Chalwe et al. (2016), high soil moisture may result in a slow build-up of soil aspergillus fungal population that produces aflatoxins. This is shown by significant differences between tied ridges and other methods, especially flatbeds, which were not able to retain moisture. It is evident that the moisture retention properties of tied ridges or box ridges had an effect on aflatoxin accumulation, however any noticeable variability in differences in the levels of contamination between the years may 
Table 4. Total aflatoxin contamination $(\mu \mathrm{g} / \mathrm{kg})$ at Chinkhombe, Kalichero and Mount Makulu during 2016 and 2017 cropping seasons ( $\mathrm{SE}=$ standard error of mean).

Tableau 4. Contamination en aflatoxines totales $(\mu \mathrm{g} / \mathrm{kg}$ ) à Chinkhombe, Kalichero et Mount Makulu pendant les saisons de culture 2016 et 2017 (SE = erreur type de la moyenne).

\begin{tabular}{|c|c|c|c|c|c|c|c|}
\hline \multirow{2}{*}{$\begin{array}{l}\text { Cropping } \\
\text { Season }\end{array}$} & & \multicolumn{4}{|c|}{ On-Farm } & \multicolumn{2}{|c|}{$\frac{\text { On-Station }}{\text { Mount Makulu }}$} \\
\hline & & Mean $\pm \mathrm{SE}$ & Range & Mean $\pm \mathrm{SE}$ & Range & Mean \pm SE & Range \\
\hline \multirow[t]{3}{*}{2016} & Double row & $66.7 \pm 17.3$ & $1.4-146.6$ & $66.8 \pm 21.7$ & $1.2-147.0$ & $50.6 \pm 2.8$ & $43.1-56.1$ \\
\hline & Flatbed & $64.2 \pm 22.6$ & $2.4-149.9$ & $50.6 \pm 16.6$ & $2.6-147.7$ & $56.2 \pm 10.5$ & $40.3-87.1$ \\
\hline & Single row & $29.1 \pm 17.6$ & $1.6-137.0$ & $42.6 \pm 13.9$ & $1-141.3$ & $25.1 \pm 4.3$ & $17.5-37.5$ \\
\hline \multirow[t]{4}{*}{2017} & Double row & $3.9 \pm 0.1$ & $3.7-4.1$ & $1.9 \pm 0.1$ & $1.7-2.2$ & $308.7 \pm 185.2$ & $12.5-784.8$ \\
\hline & Flatbed & $13.0 \pm 9.5$ & $3.7-32.4$ & $1.7 \pm 0.2$ & $1.2-2.4$ & $172.4 \pm 41.1$ & $95.6-278.0$ \\
\hline & Single row & $4.5 \pm 0.2$ & $3.7-4.9$ & $1.3 \pm 0.1$ & $1.2-1.4$ & $124.4 \pm 53.7$ & $34.2-249.5$ \\
\hline & Tied ridging & $2.3 \pm 0.4$ & $1.7-3.8$ & $0.9 \pm 0.1$ & $0.8-1.1$ & $56.9 \pm 17.5$ & $21.1-95.6$ \\
\hline
\end{tabular}

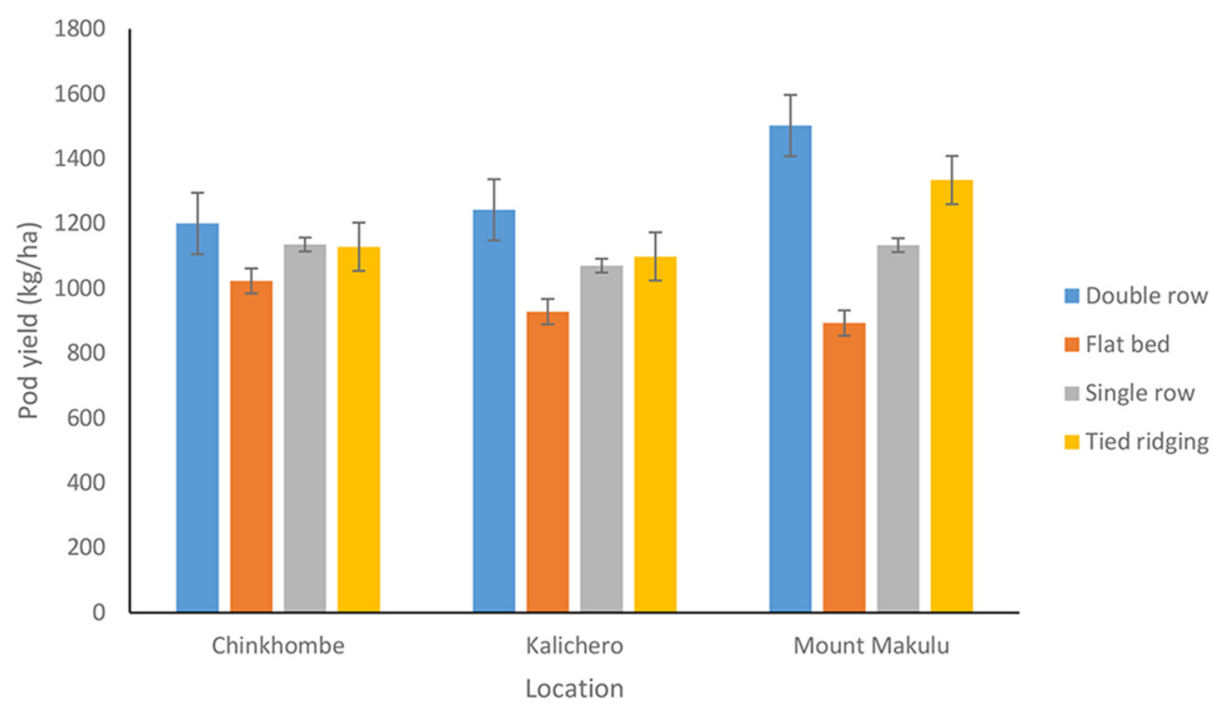

Fig. 3. Effect of different treatments on the pod yield (kg/ha) at Chinkhombe, Kalichero and Mount Makulu during 2017 cropping season. Fig. 3. Effet des différents traitements sur le rendement en gousses $(\mathrm{kg} / \mathrm{ha})$ à Chinkhombe, Kalichero et Mount Makulu pendant la saison de culture 2017.

have resulted from the crop experiencing mid-season dry spells or end-season drought during the cropping season such as in 2016 (FEWSNET, 2016), soil type and the delay planting that occurred in the researcher managed trials at Mount Makulu in 2017.

Although significantly high pod yields were obtained from groundnuts planted on tied ridges compared to flatbeds and in single rows, this was nonetheless less than yields obtained by planting groundnuts in double rows. The high pod yields realized in double rows were probably due to the high plant stand. Balkcom et al. (2010) found that planting groundnuts in double rows often resulted in increased productivity and had the potential benefits of maintaining surface residual moisture. It is likely that the high pod yield obtained in tied ridges may have resulted from better soil moisture retention and soil aeration effects, which promoted good groundnut plant vigour and vegetative growth unlike in the other three treatments. These observations are in agreement with those of Hulugalle (1988) who reported higher dry matter yield of Bambara groundnuts when planted on tied ridges compared to planting in flatbeds.

Even though the levels of aflatoxins both in 2016 and in 2017 were still higher than the acceptable safe limit of $10 \mu \mathrm{g} / \mathrm{kg}$ in tied ridges, especially at Mount Makulu, it is very clear from the study that tied ridging if used in conjunction with other methods would be able to manage the risk associated with aflatoxins. In addition, conducting more on-farm testing ensures that more farmers are exposed to improved technologies. Farmers generally respond positively to a technology if an economical benefit trait is included in the evaluation (Fielding and Riley, 1997). According to Sibhatu and Qaim (2017), one of the major goals of the smallholder farmer is to produce enough 
Table 5. Farmer assessment of the different groundnut field preparation methods during 2017 cropping season at Chinkhombe and Kalichero $(1=$ Excellent; 2 = Good; 3 =Fair; $4=$ Poor; $5=$ Worse $)$.

Tableau 5. Evaluation par les paysans des différentes méthodes de préparation des parcelles d'arachide pendant la saison de culture 2017 à Chinkhombe et Kalichero ( $1=$ Excellent; 2=Bon; $3=$ Passable; $4=$ Mauvais ; $5=$ Très mauvais $)$.

\begin{tabular}{|c|c|c|c|c|c|c|c|c|c|c|c|c|}
\hline Site & Treatment & $\begin{array}{l}\text { Vegetative } \\
\text { growth }\end{array}$ & Weeds & $\begin{array}{l}\text { Drought } \\
\text { tolerance }\end{array}$ & Diseases & Pests & Pod size & $\begin{array}{l}\text { Black pods } \\
\text { /roots }\end{array}$ & $\begin{array}{l}\text { Labour } \\
\text { needs }\end{array}$ & Yield & Total & Overall Rank \\
\hline \multirow{3}{*}{$\begin{array}{l}\text { Chinkhombe } \\
(n=40)\end{array}$} & Double row & 2 & 2 & 2 & 4 & 4 & 4 & 3 & 2 & 1 & 24 & 3 \\
\hline & Tied ridging & 1 & 2 & 1 & 2 & 2 & 1 & 3 & 4 & 2 & 18 & 1 \\
\hline & Flatbed & 2 & 3 & 3 & 2 & 3 & 2 & 3 & 1 & 3 & 22 & 4 \\
\hline \multirow{2}{*}{$\begin{array}{l}\text { Kalichero } \\
(n=40)\end{array}$} & Tied ridging & 1 & 2 & 1 & 2 & 1 & 2 & 1 & 4 & 2 & 16 & 1 \\
\hline & Flatbed & 3 & 2 & 4 & 4 & 3 & 3 & 3 & 1 & 3 & 26 & 4 \\
\hline
\end{tabular}

food to meet his/her requirements; hence, any technology that improves crop yield is likely to be more acceptable. This was confirmed by the farmers' opinion that a desirable technology is one that enhances crop yield, in this case pod yield, at the same time reduces the incidence of pests and diseases such as aflaroot (black pods or roots), which is a sign of high aspergillus spp infection and consequently high aflatoxin contamination. While yields are an easy measurement for comparing the performance of different technologies by the same farmer or to compare similar methods between locations, aflatoxin contamination is not apparent to the farmers hence other measurements should be used that could assist the farmers to reduce aflatoxin contamination on-farm. Thus the approach employed by this study in not only testing on-station but on-farm the robustness and efficacy of these technologies in reducing aflatoxin contamination created more awareness of these good agricultural practices by smallholder farmers. Farmer friendly practices as tied ridges were rated highly in reducing the incidence of weeds, pests, and diseases and in improving general plant growth and yields.

In traditional crop production systems which are very common in sub-Saharan Africa, farmers rarely apply inorganic fertilizer and other chemicals (Boaz et al., 2017). Farmers renew the soil fertility levels of their fields through the animal droppings as they usually allow their animals to freely graze the haulms after crop harvest. Most farmers at Chinkhombe and Kalichero produce groundnuts on a small-scale basis and the yields are quite low, 500-600 kg/ha (Munsaka, 2013). This could be attributed to the non-adoption of improved crop production methods that have been promoted over the years by Zambia Agriculture Research Institute and CGIAR centre like ICRISAT. The yield of an improved groundnut variety like MGV-4 is about 2-3 tons/ha (Ross and Klerk, 2012; ZARI, 2008). Farmer often considered best agricultural practices as extra expenses, strenuous or labour demanding and lack of information about the beneficial effects of these technologies. Similar findings have been reported by Wu et al. (2008), and Ross and Klerk (2012).

Since the proportion of aflatoxin contamination resulting from both poor pre- and post-harvest practices have not been fully quantified in most studies (Torres et al., 2014), it is expected that if correct measures are taken at pre-harvest, the reduction in aflatoxins could be higher. Other methods such as sorting and grading would then complement the pre-harvest control measures and result in more reduction in the levels of aflatoxins (Waliyar et al., 2015). Farmers should therefore be encouraged to use agronomic practices that promote good crop growth and low aflatoxin contamination, and produce high yields. In addition, testing these technologies on-farm would increase farmer exposure to these practices and enable them to make informed decisions. According to Conroy and Sutherland (2004), on-farm testing of promising technology is a critical step in the development, promotion, and dissemination of best agricultural practices.

\section{Conclusion}

With the issues of food safety and aflatoxin contamination in groundnuts gaining prominence especially in the international markets, groundnut producers need to be aware of and be able to access affordable mitigation solutions. While affordability is key in the upscaling process, new and relevant information on existing or previously promoted technologies based on additional aflatoxin research is needed and the impact of such mitigation strategies must be documented. The results of this study show that though several technologies have been promoted over time, only a few such as tied ridging are quite effective in reducing the levels of aflatoxins. Tied ridges have the ability to retain soil moisture in the "small ponds" between the rows at the critical times during plant growth and pods development, reducing plant stress and aflatoxin build-up in the maturing pods. Although tied ridges may be considered to be labour demanding, it is possible to produce a large percentage of groundnuts (more than 75\%) that meet the international and local market regulatory limit. As such these methods must be up-scaled for the benefit of all actors in the groundnut value chain, especially producers and consumers. At the same time, a balance must be found between pre-harvest interventions, which tackle the root causes of contamination, and the profound impact of good agricultural practices and post-harvest actions. Therefore, combining use of tied ridges with the use of resistant varieties, early planting, crop rotation, timely harvesting, and post-harvest methods would be 
effective in reducing the aflatoxin contamination in both organic and traditionally produced groundnuts. This is important especially in most parts of rural Zambia including Eastern Province where agroforestry and organic crop production systems have been widely adopted by small-scale farmers. These farmers apply very little or no chemical fertilizers and synthetic pesticides including fungicides. Tied ridges do not only conserve soil moisture and minimize preharvest aflatoxin contamination but produce higher yields than most planting methods as well.

Acknowledgments. This study was funded by the Platform for African-European Partnership in Agriculture and Rural Development (PAEPARD) - Competitive Research Fund under the project "Stemming Aflatoxin pre- and post-harvest waste in the groundnut value chain $(\mathrm{GnVC})$ in Malawi and Zambia".

\section{References}

Balkcom KS, Arriaga FS, Balkcom KB, Boykin DL. 2010. Singleand twin-row peanut production within narrow and wide strip tillage systems. Agron J 102(2): 507-512.

Bandyopadhyay R, Ortega-Beltran A, Akande A, Mutegi C, Atehnkeng J, Kaptoge L, et al. 2016. Biological control of aflatoxins in Africa: Current status and potential challenges in the face of climate change. World Mycotoxin Journal 9(5): 771-78.

Boaz N, Wachira P, Kagot V, Okoth S. 2017. Susceptibility of locally cultivated groundnut (Arachis hypogaea) varieties to aflatoxin accumulation in Homa Bay County, Kenya. African Journal of Microbiology Research 11(33): 1329-1337.

Bunyolo A, Chirwa B, Muchinda M. 1995. Agro-ecological and climatic conditions In: Muliokela SW, ed. Zambia seed technology handbook. Sweden: Ministry of Agriculture, Food and Fisheries, Berlings Arlöv, pp. 19-23.

Business Standard (2016/04/02). Chinese demand pushes up groundnut oil prices. Retrieved May 16, 2018. http://www. business-standard.com/article/markets/chinese-demand-pushesup-groundnut-oil-prices-by-15-116040200236 1.html.

CAST. 2003. Mycotoxins-Risks in plant, animal and human systems. Task Force Report, No. 139. Council for Agricultural Science and Technology, Iowa, pp. 1-191.

Chalwe H, Mweetwa AM, Lungu OI, Phiri E, Njoroge S, Brandenburg RL. 2016. Reducing pre-harvest aflatoxin content in groundnuts through soil water management. RUFORUM Working Document Series 14(1): 921-926.

Chapoto A, Chisanga B. 2016. Zambia Agriculture Status Report 2016. Lusaka, Zambia: Indaba Agricultural Policy Research Institute, IAPRI, 49p.

Conroy C, Sutherland A. 2004. Participatory technology development with resource-poor farmers: Maximizing impact through the use of recommendation domains. AGREN Network Paper 133. London, UK: Overseas Development Institute. http://www.odi.org.uk/

Cotty PJ, Mellon JE. 2006. Ecology of aflatoxin-producing fungi and biocontrol of aflatoxin contamination. Mycotoxin Research 22(2): 110-117. Doi: 10.1007/BF02956774.

CSO. 2016. The 2015 living conditions monitoring survey (LCMS) Report. Lusaka, Zambia: Report, Central Statistical Office, 194 p. http://www.zamstats.gov.zm/

FEWSNET. 2016. Rainfall forecast for 2015/16 agricultural season. The season monitor issue \#5. Botswana: SADC FANR Directorate, Gaborone, pp. 1-5.
Fielding WJ, Riley J. 1997. How big should on-farm trials be and how many plots should be measured? PLA Notes, IIED: London, UK, Issue 29, pp. 19-22.

Freeman HA, Van der Merwe PJA, Subrahmanyam P, Chiyembekeza AJ, Kaguongo W. 2002. Assessing adoption potential of new groundnut varieties in Malawi. Expl Agric 38: 211-221.

Gebreselassie R, Dereje A, Solomon H. 2014. On-Farm Pre Harvest Agronomic Management Practices of Aspergillus Infection on Groundnut in Abergelle, Tigray. J Plant Pathol Microb 5: 228. Doi: 10.4172/2157-7471.1000228.

Giesbrecht FG, Whitaker TB. 1998. Investigations of the problems of assessing aflatoxin levels in peanuts. Biometrics 54: 739-753.

Guchi E. 2015. Aflatoxin Contamination in Groundnut (Arachis hypogaea L.) Caused by Aspergillus Species in Ethiopia. Journal of Applied \& Environmental Microbiology 3.1 2015: $11-19$.

Guerena W, Adam K. 2008. Peanuts: Organic Production. National Sustainable Agriculture Information Service-National Center for Appropriate Technology (NCAT). [Access: 2018/08/03]. https:// attra.ncat.org/attra-pub/summaries/summary.php?pub1/495, 20 p.

Hulugalle NR. 1988. Intercropping millet and Bambara groundnut on tied ridges in the Sudan savannah of Burkina Faso. Arid Soil Research and Rehabilitation 2(2): 97-109.

JAICAF. 2008. Agriculture and forestry in Zambia: Present situation and issues for development. Akasaka, Minato-ku, Tokyo, Japan: Japan Association for International Collaboration of Agriculture and Forestry, pp. 2-9.

Marechera G, Ndwiga G. 2014. Farmers perceptions of aflatoxin management strategies in lower Eastern Kenya. Journal of Agricultural Extension and Rural Development 16(2): 382-392.

Matumba L, Poucke Van C, Ediage EN, Saeger S De. 2015. Concentrating aflatoxins on the domestic market through groundnut export: a focus on Malawian groundnut value and supply chain. Food Control 51: 236-239.

Mofya-Mukuka R, Shipekesa AM. 2013. Value chain analysis of the groundnuts sector in the Eastern Province of Zambia. Lusaka, Zambia: Indaba Agricultural Policy Research Institute, IAPRI Working Paper No. 78, pp. 1-51.

Monyo ES, Osiru MO, Kadyampakeni D, Mponda O, Chinyamunyamu B (ed). 2009. Improving food security and nutrition in Malawi and Tanzania through research on edible legumes. Proceedings of Stakeholder Workshops on Groundnut Production in Malawi and Tanzania, 1-2 March and 13 April 2007, Lilongwe (Malawi) and Mtwara (Tanzania). Patancheru 50 2324, Andhra Pradesh, India: International Crops Research Institute for the SemiArid Tropics. 96 p. ISBN: 978-92-9066-515-1.

Munsaka E. 2013. Factors influencing the productivity of groundnuts among smallholder farmers in Zambia's Eastern Province. BSc. Agric Diss. UNZA: Lusaka, 35 p.

Muzari W, Gatsi W, Muvhunzi S. 2012. The impacts of technology adoption on smallholder agricultural productivity in sub-Saharan Africa: A review. Journal of Sustainable Development 5(8): 69-77. DOI: $10.5539 /$ jsd.v5n8p69.

Njoroge SMC, Matumba L, Kanenga K, Siambi M, Waliyar F, Maruwo J, et al. 2016. A case for regular monitoring in peanut butter in sub-Saharan Africa: Lessons from a 3-year survey in Zambia. J Food Prot 79(5): 795-800.

Ross S, Klerk M De. 2012. Groundnut value chain and marketing assessment in Eastern Province of Zambia. Lusaka, Zambia: Prepared for the conservation farming unit, pp. 1-44.

Sibhatu KT, Qaim M. 2017. Rural food security, subsistence agriculture, and seasonality. PLoS ONE 12(10): e0186406. DOI: 10.1371/journal.pone.0186406. 
Simtowe F, Asfaw S, Abate T. 2016. Determinants of agricultural technology adoption under partial population awareness: the case of pigeon pea in Malawi. Agricultural and Food Economics 4(7). DOI: 10.1186/s40100-016-0051-z.

Sugri I, Osiru M, Abudulai M, Abubakari M, Asieku Y, Lamini S, et al. 2017. Integrated peanut aflatoxin management for increase income and nutrition in Northern Ghana. Cogent Food Agriculture 3: 1. DOI: 10.1080/23311932.2017.1312046.

Torres AM, Barros GG, Palacios SA, Chulze SN, Battilani P, Traore A, et al. 2014. Review on pre- and post-harvest management of peanuts to minimize aflatoxin contamination. Food Research International 62: 11-19.

Villers P. 2014. Aflatoxins and safe storage. Front. Microbiol. 5(158): 1-6. DOI: 10.3389/fmicb.2014.00158.

VSN International. 2015. Genstat for Windows 18th Edition. VSN International, Hemel Hempstead: UK. Web page: Genstat.co.uk.

Waliyar F, Kumar L, Traoré A, Ntare BR, Diarra B, Kodio O. 2008. Pre-and post-harvest management of aflatoxin contamination in peanuts. In: Leslie JF, Bandyopadhyay R, Viscont A, ed.
Mycotoxins: Detection methods, management, public health and agricultural trade. UK: Wallingford: CAB International, pp: 209 218

Waliyar F, Osiru M, Ntare BR, Kumar KVK, Sudini H, Traore A, et al. 2015. Post-harvest management of aflatoxin contamination in groundnut. World Mycotoxin Journal 8(2): 245-252.

Whitaker TB, Dickens JW, Monroe RJ. 1974. Variability of aflatoxin test results. J Am Oil Chem Soc 51(5): 214-218.

Whitaker TB, Springer J, Defize PR, Coker R. 1995. Evaluation of sampling plans used in the United States, United Kingdom, and The Netherlands to test raw shelled peanuts for aflatoxin. $J A O A C$ Int 78 (4): 1010-1018.

Winter CK, Davis SF. 2006. Organic foods. Journal of Food Science 71(9): R117-R124.

Wu F, Liu Y, Bhatnagar D. 2008. Cost-effectiveness of aflatoxin control methods: Economic incentives. Toxin Reviews 27: $203-$ 225.

ZARI. 2008. Annual Report. Zambia Agriculture Research Institute: Lusaka, Zambia.

Cite this article as: Mukanga M, Matumba L, Makwenda B, Alfred S, Sakala W, Kanenga K, Chancellor T, Mugabe J, Bennett B. 2019. Participatory evaluation of groundnut planting methods for pre-harvest aflatoxin management in Eastern Province of Zambia. Cah. Agric. 28: 1. 